Vol 10, Issue 10, 2017

\title{
ANTIDIABETIC ACTIVITY OF EXTRACT, FRACTIONS, AND ASIATICOSIDE COMPOUND ISOLATED FROM CENTELLA ASIATICA LINN. LEAVES IN ALLOXAN-INDUCED DIABETIC MICE
}

\author{
EKA FITRIANDA ${ }^{1,2 *}$, ELIN YULINAH SUKANDAR ${ }^{1}$, ELFAHMI $^{1}$, I KETUT ADNYANA ${ }^{1}$ \\ ${ }^{1}$ Department of Pharmacy, Pharmacology-Clinical Pharmacy Research Group, School of Pharmacy, Institut Teknologi Bandung, Bandung, \\ Indonesia. ${ }^{2}$ Department of Pharmacy, STIFI Perintis Padang, Padang, Indonesia. Email: ekafitrianda@yahoo.com
}

Received: 01 June 2017, Revised and Accepted: 30 June 2017

\section{ABSTRACT}

Objective: Centella asiatica Linn. is known and used as traditional antidiabetic drug especially in ayurvedic traditional system in some countries. The main objective of this study was to evaluate antidiabetic activity of ethanolic extract, saponin-rich fraction (SRF), nonsaponin fraction (NSF), and asiaticoside compound isolated from C. asiatica Linn. leaves in alloxan-induced diabetic mice.

Methods: Diabetes was induced in albino mice by administration of alloxan monohydrate $(60 \mathrm{mg} / \mathrm{kg}$ i.v). Extract was administrated orally each in doses of 125,250 and $500 \mathrm{mg} / \mathrm{kg}$, the SRF and NSF were in doses of 75, 150 and $300 \mathrm{mg} / \mathrm{kg}$, while the asiaticoside was administrated in doses of $1.4,2.8$ and $5.6 \mathrm{mg} / \mathrm{kg}$ for 21 days. Blood fasting glucose level, insulin level, and glycosylated hemoglobin level were measured, and histopathology of pancreas was observed to determine antidiabetic activity of each sample.

Results: Decreased blood fasting glucose level, increased insulin, and decreased glycosylated hemoglobin were observed in diabetic mice treated with extract, SRF and asiaticoside. On $21^{\text {st }}$ day, extract at dose $500 \mathrm{mg} / \mathrm{kg}$, SRF at dose $300 \mathrm{mg} / \mathrm{kg}$, and asiaticoside at dose $5.6 \mathrm{mg} / \mathrm{kg}$ gave lowest blood glucose level in their each group which were $239 \pm 8.0,254 \pm 10.4$, and $217 \pm 8.1 \mathrm{mg} / \mathrm{dl}$, respectively, compared to control group at $290 \pm 14.8 \mathrm{mg} / \mathrm{dl}$. Insulin level of these three groups was $19.4 \pm 0.59,24.8 \pm 0.99$, and $27.8 \pm 0.77 \mu \mathrm{IU} / \mathrm{ml}$, respectively, the highest value in their each group compared to $7.28 \pm 0.34 \mu \mathrm{IU} / \mathrm{ml}$ in control group. Meanwhile glycated hemoglobin level of these groups was $2.040 \pm 0.08,2.010 \pm 0.04$, and $2.11 \pm 0.07 \mathrm{ng} / \mathrm{ml}$, respectively, lowest value in their each group compared to control group at $2.76 \pm 0.06 \mathrm{ng} / \mathrm{ml}$. However, histopathology study in these groups did not show any improvements in regeneration of $\beta$-cells of pancreas. In the other side, NSF treatment did not affect any the parameters mentioned above.

Conclusions: It can be concluded that extract, SRF and asiaticoside isolated from C. asiatica Linn. possess significant antidiabetic activity in diabetic mice. Based on increased levels of insulin and histopathology studies of pancreatic tissue, antidiabetic activity of those samples was believed to occur through the mechanism of increasing secretion of healthy pancreatic $\beta$-cells without any ability to regenerate $\beta$-cells that were damaged by alloxan.

Keywords: Centella asiatica, Fraction, Asiaticoside, Diabetes mellitus, Alloxan.

(c) 2017 The Authors. Published by Innovare Academic Sciences Pvt Ltd. This is an open access article under the CC BY license (http://creativecommons. org/licenses/by/4. 0/) DOI: http://dx.doi.org/10.22159/ajpcr.2017.v10i10.20419

\section{INTRODUCTION}

At present, the incidence of diabetes mellitus (DM) is increasing worldwide, especially in Asia. The number of diabetic patients in the world is estimated as many as 171 million people in 2000 and is predicted to increase up to 366 million people in 2030 [1]. In countries that recognize ayurvedic traditional medicine system such as India and Bangladesh, Centella asiatica has been used as a remedy for DM since 100 years ago [2,3]. C. asiatica or Hydrocotyle asiatica is known as Gotu kola, Asiatic pennyworth, Indian pennywort, Indian water navelwort, wild violet and tiger herb in English [4]. While in countries that use the Malay language, such as Indonesia, Malaysia and Brunei Darussalam, it is known by the name pegaga or pegagan [5]. C. asiatica is known as Brahmi or mandukaparni in India [6]. In these countries, beside used as medicinal plants, $C$. asiatica is also commonly eaten as fresh vegetables, cooked, and drinks $[7,8]$. Terpenes, essential oils, flavonoids, tannins, phytosterols, amino acids, and sugars have been isolated or detected in this plant $[8,9]$.

The objective of this study was to explore deeper the results of the previous research to find out fraction of $C$. asiatica Linn. which possess antidiabetic activity, the action mechanism and what compound responsible for the action.

\section{METHODS}

Preparation of plant extract, fractions, and asiaticoside The fresh leaves of the $C$. asiatica were collected from Payakumbuh, West Sumatera, Indonesia. The specimen was identified at herbarium of School of Biological Science and Technology, Institut Teknologi Bandung with specimen number of 211/11C02.2/PL/2016. The leaves were shade dried for 6 days and powdered using dry grinder. This powder was macerated with $97 \%$ ethanol; the extract obtained was concentrated using a rotary evaporator to produce a concentrated extract. Acetone was used to separate the saponin-rich fraction (SRF) with nonsaponin fraction (NSF). The ethanolic extract was dissolved in acetone; the precipitate formed was separated and dried, while soluble portion also concentrated by using a rotary evaporator. The precipitate obtained was the SRF and the concentrated soluble portion was the NSF [10]. Asiaticoside compound was provided (including isolated and identified) by Prof. Dayar Arbain from Andalas University, Indonesia.

Chemical

Alloxan monohydrate was purchased from Sigma-Aldrich, St. Louis, USA. All other reagents used were of analytical grade.

\section{Instrument}

Glucometer (Auto-Check®) was used to measured blood glucose level of mice. While infinite 200 pro multifunctional microplate reader (Tecan $\left.{ }^{\circledR}\right)$ was used to measure absorbance in determining blood insulin and glycated hemoglobin (HbA1c) level.

\section{Animals}

Laboratory bred 3-4 months ddY strain male albino mice weighing about 20-30 g are used under standard animal housing condition (temperature controlled $25 \pm 2^{\circ} \mathrm{C}$ and maintained with $12 \mathrm{hrs}$ light/ 
dark cycle) with unlimited access to standard food and water ad libitum throughout the study in the animal house, department of pharmacology, school of pharmacy, Institut Teknologi Bandung. All animal protocols in this research were approved by animal research ethics committee of School of Pharmacy, Institut Teknologi Bandung, with certificate number of 08/KEPHP-ITB/09-2016.

\section{Oral glucose tolerance test (OGTT) in normal mice}

OGTT was performed in overnight fasted normal rats. Normal mice were divided into 14 groups, each consisting of five rats. Animals in the second group were treated with glibenclamide $(6.5 \mathrm{mg} / \mathrm{kg})$, animals in group third until fifth were treated with ethanolic extract at a dose of 125, 250 and $500 \mathrm{mg} / \mathrm{kg}$, animals in group sixth until eighth were treated with SRF at a dose of 75,150 and $300 \mathrm{mg} / \mathrm{kg}$, animals in group ninth until eleventh were treated with NSF at a dose of 75, 150 and $300 \mathrm{mg} / \mathrm{kg}$ and animals in group $12^{\text {th }}$ until $14^{\text {th }}$ were treated with asiaticoside at a dose of $1.4,2.8$ and $5.6 \mathrm{mg} / \mathrm{kg}$. All tested materials were given orally. Glucose $(2 \mathrm{~g} / \mathrm{kg}$ ) was fed 30 minutes after the administration of tested materials [11]. Control animals were administered with an equal volume of water. The level of blood glucose was measured using glucometer at 0 , $15,30,60$, and 120 minutes of glucose administration.

\section{Induction of diabetes}

Diabetes was induced in male Swiss albino mice by administration of alloxan monohydrate (Sigma-Aldrich Co., USA) dissolved in normal saline intravenously in dose of $65 \mathrm{mg} / \mathrm{kg}$ [11]. Blood glucose was measured after $24 \mathrm{hrs}$ of alloxan injection by using glucometer. Mice showing fasting blood glucose levels $>250 \mathrm{mg} / \mathrm{dl}$ were selected for the study [12].

\section{Treatment}

Animals were divided into 15 groups, each consisting of five mice. Standard food and water was provided to the animals. Some treatments were done to the mice according to the group they were belongs to.Group 1 (normal untreated) and Group 2 (diabetic control) were given only vehicle (Na CMC $0.5 \%$ ), Group 3 was treated with glibenclamide $(6.5 \mathrm{mg} / \mathrm{kg})$ orally as standard drug, Groups 4-6 were treated with the extract at dose of 125,250 and $500 \mathrm{mg} / \mathrm{kg}$, Groups 7-9 were treated with SRF at dose of 75, 150 and $300 \mathrm{mg} / \mathrm{kg}$, Groups $10-12$ were treated with the NSF at dose of 75, 150 and $300 \mathrm{mg} / \mathrm{kg}$, Groups 13-15 were treated with asiaticoside at dose of $1.4,2.8$ and $5.6 \mathrm{mg} / \mathrm{kg}$, respectively. All of tested materials, standard drug and vehicle were administrated orally once a day for 21 days [13]

The level of fasting blood glucose was measured in $7^{\text {th }}, 14^{\text {th }}$, and $21^{\text {st }}$ day after treatment by using glucometer [13]. The insulin and HbA1c level were measured in $21^{\text {st }}$ day through blood collection by tail prick using RayBio ${ }^{\circledR}$ mouse insulin enzyme-linked immunosorbent assay (ELISA) kit and Elabscience ${ }^{\circledR}$ mouse HbA1c ELISA kit. In $22^{\text {nd }}$ day, all the experimental animals were sacrificed by cervical dislocation and histopathology observation was done to investigate any changes in Langerhans of pancreas organ [14].

\section{Statistical analysis}

All data obtained in this research were subjected into analysis of variance (ANOVA) together with Duncan test $(\mathrm{p}<0.05$ and $\mathrm{p}<0.01)$, as significantly different between control and experimental data.

\section{RESULTS}

Effect of C. asiatica L. on OGTT in normal rats

Measurement of blood glucose levels was done at $0,15,30,60$, and 120 minutes after oral glucose administration. Decreased glucose levels were seen in minute 15, 30, and 60 in the extract group at all doses, SRF group at all doses, as well as asiaticoside group at all doses compared to blood glucose levels in the normal control group. In the 120 minutes, only extract group at a dose of $500 \mathrm{mg} / \mathrm{kg}$ and asiaticoside group at dose of $2.8 \mathrm{mg} / \mathrm{kg}$ which showed a decrease in glucose levels compared to normal control group. Meanwhile, the NSF group did not show any decrease in blood glucose levels at all points of measurement.
The effect of $C$. asiatica $L$. on fasting blood glucose in alloxaninduced diabetic mice

Increasing level of fasting blood glucose occurred in $24 \mathrm{hrs}$ after induction of diabetes in mice using alloxan monohydrate. Extract, fractions, and asiaticoside were administrated for 21 days. On the $7^{\text {th }}, 14^{\text {th }}$ and $21^{\text {st }}$ day, fasting blood glucose levels in each group were monitored. As a result, blood glucose levels were decrease on the $7^{\text {th }}$ day in asiaticoside group at dose of 2.8 and $5.6 \mathrm{mg} / \mathrm{kg}$. While on day 14 and 21, decreasing in blood glucose levels observed in extract group at all doses, SRF group at all doses, as well as asiaticoside group also at all doses. Meanwhile, there was no decreasing in glucose levels in all groups of NSF.

\section{The effect of $C$. asiatica $\mathrm{L}$. on HbA1c level in alloxan-induced} diabetic mice

HbA1c levels were measured on day 21, decreased levels of HbA1c only significant at the highest dose of the extract, SRF and asiaticoside group. Groups experienced a significant reduction in HbA1c levels compared to control group were the extract at dose of $500 \mathrm{mg} / \mathrm{kg}$, SRF at dose of $300 \mathrm{mg} / \mathrm{kg}$, and asiaticoside at dose of $5.6 \mathrm{mg} / \mathrm{kg}$.

\section{The effect of $C$. asiatica L. on insulin level in alloxan-induced} diabetic mice

Blood insulin levels were measured at day 22 after treatment. Measurement results showed an increase in insulin levels at all doses of extract group, all doses of SRF, and all doses of asiaticoside group compared to control group. While administration of NSF at all doses did not affect insulin levels significantly.

\section{Histopathology of pancreas}

Histopathological examination of pancreatic tissue is done through Gomori staining. A number of island of Langerhans was counted in the slice. As a result, there was no significant difference in the number of island of Langerhans due to treatment compared to the control group. In addition, observation was also done to the shape and size of island of Langerhans, but no significant different was observed due to the treatment.

The values are expressed as mean \pm SEM. $n=6$ slices in each group. Statistical analysis to compare control group with other groups was done by ANOVA test. No significant different between groups.

\section{DISCUSSION}

In this study, we did the OGTT and test on alloxan-induced diabetic in mice to investigate antidiabetic activity of extract, SRF, NSF and asiaticoside. In OGTT, decreased glucose levels, especially at 60 minutes after glucose loading was detected in the extract, SRF and asiaticoside group. Table 1 and Fig. 1 showed significantly decreased levels of blood glucose in all three groups in all doses when compared to the control group. This indicates that these materials can improve the cells ability to use glucose.

Rapid destruction of pancreatic $\beta$-cells due to alloxan was due to simultaneous massive increase in cytosolic calcium concentration. This increasing was caused by redox cycle with the formation of superoxide radicals following alloxan administration [15]. The most frequently used intravenous dose of alloxan in rats is $65 \mathrm{mg} / \mathrm{kg}[16,17]$. In this study, diabetes induction using alloxan performed by administering it through intravenous route. Diabetic conditions are obtained after 24 hrs of injection of alloxan.

All of the samples in this study were given orally as a single dose for 21 days. The parameters measured including fasting blood glucose level, insulin level, HbA1c level, and histopathology of pancreas.

In OGTT, it was found that extract, SRF, and asiaticoside treatments could decrease blood fasting glucose level significantly after oral glucose intake, compared to normal control animals, started from minute 15 as seen in Table 1. In alloxan-induced diabetes model, extract 
Table 1: Effect of $C$. asiatica L. on OGTT in normal mice

\begin{tabular}{|c|c|c|c|c|c|}
\hline \multirow[t]{2}{*}{ Treatment of groups $(\mathrm{mg} / \mathrm{kg} / \mathrm{day})$} & \multicolumn{5}{|c|}{ Blood glucose level (mg/dl) } \\
\hline & 0 minute & 15 minutes & 30 minutes & 60 minutes & 120 minutes \\
\hline Normal & $124 \pm 3.4$ & $334 \pm 10.8$ & $278 \pm 11.4$ & $179 \pm 13.9$ & $141 \pm 15.5$ \\
\hline Extract 125 & $123 \pm 2.1$ & $264 \pm 13.5^{* *}$ & $241 \pm 20.9 *$ & $160 \pm 12.1^{* *}$ & $146 \pm 12.5$ \\
\hline Extract 250 & $126 \pm 3.5$ & $240 \pm 10.8^{* *}$ & $196 \pm 18.3^{* *}$ & $162 \pm 26.9^{* *}$ & $129 \pm 9.4$ \\
\hline Extract 500 & $125 \pm 3.4$ & $211 \pm 7.9^{* *}$ & $197 \pm 10.9^{* *}$ & $136 \pm 10.5^{* *}$ & $122 \pm 5.6^{*}$ \\
\hline SRF 75 & $128 \pm 3.4$ & $249 \pm 12.3^{* *}$ & $244 \pm 19.1^{*}$ & $148 \pm 11.2^{* *}$ & $133 \pm 9.4$ \\
\hline SRF 150 & $127 \pm 3.9$ & $242 \pm 5.6^{* *}$ & $248 \pm 12.8$ & $147 \pm 6.3^{* *}$ & $129 \pm 5.1$ \\
\hline SRF 300 & $127 \pm 4.1$ & $246 \pm 13.3^{* *}$ & $244 \pm 5.8^{*}$ & $141 \pm 16.1^{* *}$ & $127 \pm 10.5$ \\
\hline NSF 75 & $127 \pm 2.8$ & $308 \pm 51.1$ & $277 \pm 14.1$ & $183 \pm 19.1$ & $152 \pm 11.6$ \\
\hline NSF 150 & $128 \pm 5.5$ & $314 \pm 13.1$ & $263 \pm 8.6$ & $201 \pm 17.7$ & $167 \pm 16.7$ \\
\hline NSF 300 & $124 \pm 3.6$ & $324 \pm 13.0$ & $278 \pm 57.9$ & $188 \pm 19.7$ & $171 \pm 18.6$ \\
\hline Asiaticoside 1.4 & $126 \pm 4.4$ & $240 \pm 52.6^{* *}$ & $234 \pm 12.5^{*}$ & $162 \pm 8.3^{* *}$ & $134 \pm 12.6$ \\
\hline Asiaticoside 2.8 & $127 \pm 7.1$ & $239 \pm 23.4^{* *}$ & $256 \pm 47.2$ & $143 \pm 14.5^{* *}$ & $119 \pm 11.0 *$ \\
\hline Asiaticoside 5.6 & $124 \pm 3.1$ & $239 \pm 17.9^{* *}$ & $222 \pm 9.2^{* *}$ & $133 \pm 20.3^{* *}$ & $128 \pm 17.5$ \\
\hline
\end{tabular}

The values are expressed as mean \pm SEM. $n=5$ animals in each group. Statistical analysis to compare normal group with other group was done by ANOVA, followed by Duncan test. Values *was statistically different compared to normal group, p<0.05, values ${ }^{* *}$ was statistically different compared to normal group, p<0.01, OGTT: Oral glucose tolerance test, $C$. asiatica: Centella asiatica

Table 2: Effect of $C$. asiatica $L$. on fasting blood glucose in alloxan-induced diabetic mice

\begin{tabular}{|c|c|c|c|c|}
\hline \multirow[t]{2}{*}{ Treatment of groups (mg/kg/day) } & \multicolumn{4}{|c|}{ Fasting blood glucose (mg/dl) } \\
\hline & 0 day & $7^{\text {th }}$ day & $14^{\text {th }}$ day & $21^{\text {st }}$ day \\
\hline Normal & $121 \pm 11.9$ & $120 \pm 5.3^{* * y}$ & $122 \pm 5.4^{* * y}$ & $120 \pm 8.6^{* * y}$ \\
\hline Glibenclamide 6.5 & $279 \pm 12.7^{* * x}$ & $162 \pm 12.6^{* * y}$ & $152 \pm 5.8^{* * y}$ & $148 \pm 8.3^{* * y}$ \\
\hline Extract 125 & $282 \pm 24.4^{* * x}$ & $279 \pm 19.0$ & $265 \pm 7.5^{* y}$ & $264 \pm 5.2^{* y}$ \\
\hline Extract 250 & $300 \pm 32.9 * * x$ & $283 \pm 23.9$ & $256 \pm 15.8^{* * y}$ & $255 \pm 15.3^{* * y}$ \\
\hline Extract 500 & $304 \pm 44.7^{* * x}$ & $270 \pm 10.3$ & $246 \pm 8.9 * * y$ & $239 \pm 8.0 * * y$ \\
\hline SRF 75 & $287 \pm 28.6^{* * x}$ & $283 \pm 21.6$ & $265 \pm 13.0^{* y}$ & $263 \pm 18.7^{* * y}$ \\
\hline SRF 150 & $295 \pm 31.5^{* * x}$ & $279 \pm 14.7$ & $267 \pm 19.6^{* y}$ & $267 \pm 12.8^{* y}$ \\
\hline SRF 300 & $281 \pm 15.5^{* * x}$ & $275 \pm 8.6$ & $253 \pm 9.4^{* * y}$ & $254 \pm 10.4^{* * y}$ \\
\hline NSF 75 & $288 \pm 11.6^{* * x}$ & $289 \pm 14.1$ & $288 \pm 15.4$ & $290 \pm 13.7$ \\
\hline NSF 150 & $282 \pm 13.8^{* * x}$ & $281 \pm 8.5$ & $271 \pm 14.8$ & $276 \pm 11.7$ \\
\hline NSF 300 & $284 \pm 25.9^{* * x}$ & $279 \pm 17.8$ & $281 \pm 20.3$ & $283 \pm 19.3$ \\
\hline Asiaticoside 1.4 & $291 \pm 14.5^{* * x}$ & $284 \pm 14.3$ & $258 \pm 21.8^{* * y}$ & $255 \pm 17.0^{* * y}$ \\
\hline Asiaticoside 2.8 & $270 \pm 10.5^{* * x}$ & $261 \pm 7.0 * \mathrm{y}$ & $234 \pm 13.3^{* * y}$ & $236 \pm 22.9^{* * y}$ \\
\hline Asiaticoside 5.6 & $284 \pm 23.6^{* * x}$ & $257 \pm 12.3^{* * y}$ & $217 \pm 7.9^{* * y}$ & $217 \pm 8.1^{* * y}$ \\
\hline
\end{tabular}

and SRF began to cause a decrease in blood glucose levels after 14 days of use. Asiaticoside at doses of 2.8 and $5.6 \mathrm{mg} / \mathrm{kg}$ started to give the effect of a decrease in fasting blood glucose in diabetic mice on day 7. While the NSF did not show a decrease in fasting blood glucose levels up to 21 days as seen in Table 2 .

Antidiabetic activity of $C$. asiatica extracts has been reported previously in diabetic rats induced by alloxan $[18,19]$. In this study, the test was performed in mice, and we investigated which fraction is responsible for its antidiabetes activity. Further, we investigated which compound is actually responsible for the actions. The ethanolic extract of $C$. asiatica was divided into two fractions, namely, RSF and NSF.

C. asiatica contains many biochemical constituents, but only the group of terpenes which are considered as the major biochemical constituents. Terpenes of $C$. asiatica obtained in various forms include monoterpenes and sesquiterpenes such as $\alpha$-copaene, $\alpha$-pinene, $\beta$-elemene, $\beta$-caryophyllene, $\beta$-pinene, trans- $\beta$-farnesene, $\gamma$-terpinene, myrcene, bornyl acetate, germacrene $\mathrm{D}$, and bicycloelemene. However, the most common terpenes with the most interesting biological activity are the class of pentacyclic triterpenes, including the glycosides and aglycons, either ursane or oleanana. Asiaticoside, asiatic acid, madecassoside,

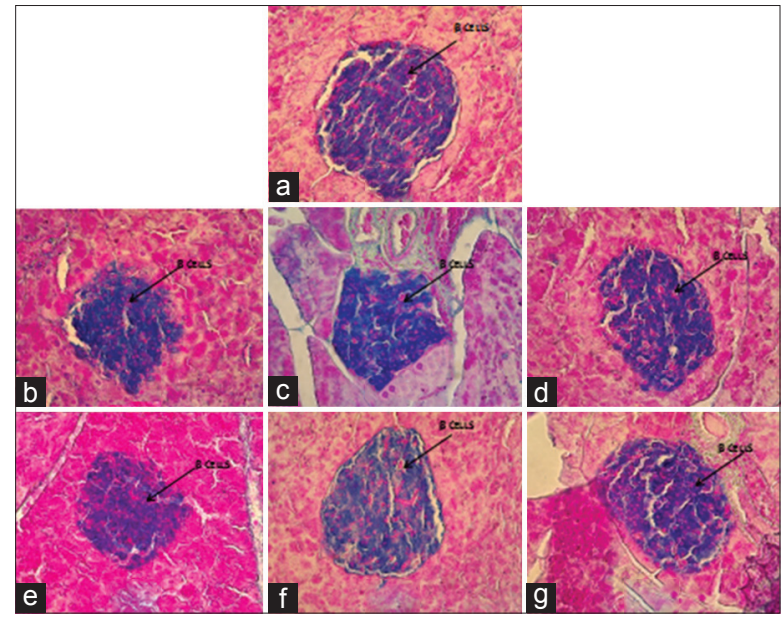

Fig. 1: Photomicrograph of island of Langerhans of each group, $40 \times$, stained by Gomori staining of (a) normal, (b) control,

(c) glibenclamide, (d) extract, (e) saponin-rich fraction, (f) nonsaponinfraction, (g) asiaticoside 
Table 3: Effect of $C$. asiatica L. on HbA1c level in alloxan-induced diabetic mice

\begin{tabular}{ll}
\hline Treatment of groups (mg/kg/day) & HbA1c level (ng/ml) \\
\hline Normal & $0.71 \pm 0.03^{* *}$ \\
Control & $2.76 \pm 0.06$ \\
Glibenclamide 6.5 & $0.75 \pm 0.03^{* *}$ \\
Extract 125 & $2.73 \pm 0.20$ \\
Extract 250 & $2.41 \pm 0.17$ \\
Extract 500 & $2.040 \pm 0.08^{* *}$ \\
SRF 75 & $2.64 \pm 0.04$ \\
SRF 150 & $2.48 \pm 0.35$ \\
SRF 300 & $2.010 \pm 0.04^{* *}$ \\
NSF 75 & $2.88 \pm 0.03$ \\
NSF 150 & $2.94 \pm 0.52$ \\
NSF 300 & $2.98 \pm 0.13$ \\
Asiaticoside 1.4 & $2.61 \pm 0.07$ \\
Asiaticoside 2.8 & $2.53 \pm 0.04$ \\
Asiaticoside 5.6 & $2.11 \pm 0.07^{* *}$ \\
\hline
\end{tabular}

The values are expressed as mean \pm SEM. $n=3$ animals in each group. Statistical analysis to compare control group with other group was done by ANOVA followed by Duncan test. Values **was statistically different compared to control group, $\mathrm{p}<0.01$, C. asiatica: Centella asiatica, HbA1c: Glycated hemoglobin

Table 4: Effect of $C$. asiatica L. on insulin level in alloxan-induced diabetic mice

\begin{tabular}{ll}
\hline Treatment of groups $(\mathbf{m g} / \mathbf{k g} / \mathbf{d a y})$ & Insulin level $(\mu \mathrm{IU} / \mathbf{m l})$ \\
\hline Normal & $49.7 \pm 1.67^{* *}$ \\
Control & $7.28 \pm 0.34$ \\
Glibenclamide 6.5 & $38.9 \pm 0.64^{* *}$ \\
Extract 125 & $12.3 \pm 1.02^{* *}$ \\
Extract 250 & $16.7 \pm 1.07^{* *}$ \\
Extract 500 & $19.4 \pm 0.59^{* *}$ \\
SRF 75 & $18.8 \pm 0.34^{* *}$ \\
SRF 150 & $19.7 \pm 1.59^{* *}$ \\
SRF 300 & $24.8 \pm 0.99^{* *}$ \\
NSF 75 & $7.86 \pm 0.75$ \\
NSF 150 & $8.43 \pm 0.31$ \\
NSF 300 & $8.51 \pm 0.38$ \\
Asiaticoside 1.4 & $16.6 \pm 1.88^{* *}$ \\
Asiaticoside 2.8 & $17.8 \pm 0.58^{* *}$ \\
Asiaticoside 5.6 & $27.8 \pm 0.77^{* *}$ \\
\hline
\end{tabular}

The values are expressed as mean \pm SEM. $n=3$ animals in each group. Statistical analysis to compare control group with other groups was done by ANOVA, followed by Duncan test. Values **was statistically different compared to control group, $\mathrm{p}<0.01$, C. asiatica: Centella asiatica

and madecassic acid are triterpenes that have been concluded by many studies as the compounds responsible for the biological activity of $C$. asiatica [20]. In addition to classes of terpenes, $C$. asiatica also contains other components such as essential oils, flavonoids, tannins, phytosterols, amino acids, and sugars [8]. From the fasting blood glucose level, it can be seen that SRF was active as anti-diabetic while NSF was not, and asiaticoside (one of triterpene saponin compound), showed an activity as antidiabetic agent.

The next parameter observed in this research was HbA1c. HbA1c is produced by the nonenzymatic glycation of hemoglobin. It is an objective marker of average glycemic control in the monitoring of patients with diabetes [21]. HbA1c is also associated with macrovascular outcomes and mortality [22-24]. The result of HbA1c measurements in this study showed that only extract, SRF and asiaticoside in highest dose which had ability in reducing HbA1c level significantly in diabetic mice as seen in Table 3.

The deficiency of insulin in mice induced by alloxan was due to damage of $\beta$-cells of pancreases by superoxide radicals [15]. This damage caused decreasing in insulin level. In this study, insulin level was raised significantly in groups treated with extract, SRF and asiaticoside as seen
Table 5: Effect of $C$. asiatica L. on number of island of langerhans in alloxan-induced diabetic mice

\begin{tabular}{ll}
\hline Treatment of groups (mg/kg/day) & $\begin{array}{l}\text { Number of island of } \\
\text { Langerhans/slice }\end{array}$ \\
\hline Normal & $13.3 \pm 1.63$ \\
Control & $1.50 \pm 1.048$ \\
Glibenclamide 6.5 & $2.16 \pm 0.98$ \\
Extract 125 & $1.50 \pm 1.0488$ \\
Extract 250 & $1.33 \pm 1.21$ \\
Extract 500 & $1.50 \pm 1.0488$ \\
SRF 75 & $1.50 \pm 0.54$ \\
SRF 150 & $1.66 \pm 1.0328$ \\
SRF 300 & $1.33 \pm 0.81$ \\
NSF 75 & $1.16 \pm 1.16$ \\
NSF 150 & $1.33 \pm 0.81$ \\
NSF 300 & $1.33 \pm 0.81$ \\
Asiaticoside 1.4 & $1.16 \pm 1.16$ \\
Asiaticoside 2.8 & $1.00 \pm 0.63$ \\
Asiaticoside 5.6 & $1.33 \pm 0.81$ \\
\hline
\end{tabular}

in Table 4. However, histopathology observation showed that there was no improvement of island of Langerhans due to any treatment as seen in Table 5 and Fig. 1. It means an increase in insulin levels observed in the group of extracts, SRF and asiaticoside were not supposed to be caused by the regeneration of $\beta$-cells of the pancreas. This increase could be due to an increase in the ability of healthy $\beta$-cells to secrete insulin.

\section{CONCLUSION}

C. asiatica Linn. had antidiabetic activity in mice. Its ethanolic extract, SRF, and asiaticoside compound showed significant antidiabetic activity in alloxan-induced diabetic mice. The mechanism of the activity is suggested by stimulating the insulin secretion of pancreas $\beta$-cells which were damaged.

\section{ACKNOWLEDGMENT}

We gratefully acknowledge the financial support from the Ministry of Research, Technology and Higher Education, Republic of Indonesia.

\section{REFERENCES}

1. Wild S, Roglic G, Green A, Sicree R, King H. Global prevalence of diabetes mellitus, estimates for the year 2000 and projections for 2030. Diabetes Care 2004;27(5):1047-53.

2. Rahman MM, Sayeed MS, Haque MA, Hassan MM, Islam SM. Phytochemical screening, antioxidant, anti-Alzheimer and antidiabetic activities of Centella asiatica. J Nat Prod Plant Resour 2012;2(4):504-11.

3. Swargiary A, Hankhray B, Brahma BK, Rahman S. Ethno-botanical study of anti-diabetic medicinal plants used by the local people of Kokrajhar district of Bodoland territorial council India. J Med Plants Stud 2013;1:51-8

4. Radhika S, Senthilkumar R, Arumugam P. A review on ethnic florae with anti-hyperglycemic efficacy. Int J Herb Med 2013;1(4):55-62.

5. de Padua LS, Bunyapraphatsara N, Lemmens RH. Plant Resources of South-East Asia. $2^{\text {nd }}$ ed. Leiden: Backhuy Publisher; 1999

6. Tiwari S, Gehlot S, Gambhir IS. Centella asiatica: A concise drug review with probable clinical uses. J Stress Physiol Biochem 2011;7(1):38-44.

7. Seevaratnam V, Banumathi P, Premalatha MR, Sundaram SP, Arumugam T. Functional properties of Centella asiatica (L): A review. Int J Pharm Pharm Sci 2012;4(5):8-14.

8. Zheng CJ, Qin LP. Chemical components of Centella asiatica and their bioactives. J Chin Integr Med 2007;5(3):348-51.

9. Shirwaikar A, Rajendran K, Barik R. Effect of aqueous bark extract of Garuga pinnata Roxb. In streptozotocin-nicotinamide induced Type-II diabetes mellitus. J Ethnopharmacol 2006;107(2):285-90.

10. Kannabiran K, Kuma M, Gunasekar V. Evaluation of antimicrobial activity of saponin isolated from Solanum xanthocarpum and Centella asiatica. Int J Nat Eng Sci 2009;3:25-28.

11. Fröde TS, Medeiros YS. Animal models to test drugs with potential 
anti-diabetic activity. J Ethnopharmacol 2008;115(2):173-83.

12. Ramya SS, Vijayanand N, Rathinavel S. Antidiabetic activity of Cynodon dactylon (L.) Pers. Extracts in alloxan induced rats. Int J Pharm Pharm Sci 2014;6:348-52

13. Tanquilut NC, Tanquilut MR, Estacio MA, Torres EB, Rosario JC, Reyes BA. Hypoglycemic effect of Lagerstroemia speciosa (L.) Pers. On alloxan-induced diabetic mice. J Med Plants Res 2009;3(12):1066-71.

14. Sruthi T, Satyavati D, Upendar K, Kumar CP. Antidiabetic activity and anti-oxidant activity of niddwin, a polyherbal formulation in alloxan induced diabetic rats. Int J Pharm Pharm Sci 2014;6(2):273-7.

15. Szudelski T. The mechanism of alloxan and streptozotocin action in cells of the rat pancreas. Physiol Res 2011;50(6):536-46.

16. Federiuk IF, Casey HM, Quinn MJ, Wood MD, Ward WK. Induction of Type-1 diabetes mellitus in laboratory rats by use of alloxan: Route of administration, pitfalls, and insulin treatment. Comp Med 2004;54(3):252-7.

17. Machado AF, Zimmerman EF, Hovland DN Jr, Weiss R, Collins MD. Diabetic embryopathy in C57BL/6J mice. Altered fetal sex ratio and impact of the splotch allele. Diabetes 2001;50(5):1193-9.

18. Chauhan PK, Pandey IP, Dhatawalia VK, Singh V. Anti-diabetic effect of ethanolic and methanolic leaves extract of Centella asiatica on allloxan induced diabetic rats. Int J Pharm Bio Sci 2010;1:1-6.

19. Gayathri V, Leksmi P, Padmadabbhan RN. Anti-diabetes mellitus activity of ethanol extract of Centella asiatica (L.) Urban (whole plant) in streptozotocin-induced diabetic rats, isolation of an active fractions and toxicity evaluation of the extract. Int J Med Aromat Plants 2011;1:278-86.

20. Alfarra HY, Omar MN. Centella asiatica: From folk remedy to the medicinal biotechnology - A state revision. Int J Biosci 2013;3(6):49-67.

21. d'Emden M. Glycated Haemoglobin for the Diagnosis of Diabetes. Australia: Australian Prescriber; 2014.

22. Stratton IM, Adler AI, Neil HA, Matthews DR, Manley SE, Cull CA, et al. Association of glycaemia with macrovascular and microvascular complications of Type 2 diabetes (UKPDS 35): Prospective observational study. BMJ 2000;321(7258):405-12.

23. Khaw KT, Wareham N, Bingham S, Luben R, Welch A, Day N. Association of hemoglobin A1c with cardiovascular disease and mortality in adults: The European prospective investigation into cancer in Norfolk. Ann Intern Med 2004;141(6):413-20.

24. Selvin E, Steffes MW, Zhu H, Matsushita K, Wagenknecht L, Pankow J, et al. Glycated hemoglobin, diabetes, and cardiovascular risk in nondiabetic adults. N Engl J Med 2010;362(9):800-11. 